This is the authors' final version of the paper published in: Tourism Review.

Original publication available at:

https://www.emeraldinsight.com/doi/pdfplus/10.1108/TR-02-2018-0018

\title{
Smart destinations and tech-savvy millennial tourists: Hype versus reality
}

Francisco Femenia-Serra $^{\mathrm{a} *}$, José Francisco Perles-Ribes ${ }^{\mathrm{b}}$, Josep A. Ivars-Baidal ${ }^{\mathrm{a}}$

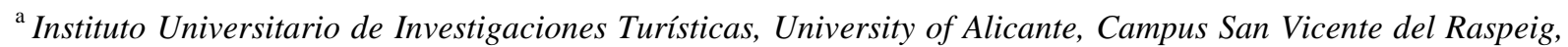
03080 Alicante, Spain

${ }^{b}$ Department of Applied Economic Analysis, Faculty of Economics and Business Sciences, University of Alicante, Campus San Vicente del Raspeig, 03080 Alicante, Spain

*Corresponding author. Email addresses: paco.femenia@ua.es (F. Femenia-Serra), josep.ivars@ua.es (J.A. Ivars-Baidal), jose.perles@ua.es (J.F. Perles-Ribes)
}

You can cite paper as:

Femenia-Serra, F., Perles-Ribes, J. F., \& Ivars-Baidal, J. A. (2018). Smart destinations and tech-savvy millennial tourists: hype versus reality. Tourism Review, (Forthcoming). http://doi.org/https://doi.org/10.1108/TR-02-2018-0018 


\title{
$\underline{\text { Smart destinations and tech-savvy millennial tourists: Hype versus reality }}$
}

Francisco Femenia-Serra, José Francisco Perles-Ribes \& Josep A. Ivars-Baidal

\begin{abstract}
Purpose: This paper aims to contrast the expectations placed on the smart destination as a theoretical management approach with the reality of emergent tech-savvy tourism demand by examining the response of this segment to three critical dimensions of technology use in the context of smart destinations. Tech-savvy tourists are here represented by highly educated Spanish millennial tourists.

Design/methodology/approach: Data were obtained through an online survey and analysed through descriptive techniques and exploratory factor analysis using SPSS. Literature review was critical for setting the foundations of the research in this novel context.

Findings: Results suggest the existence of a gap between the smart destination theoretical expectations and created hype and the real response of the examined demand in the three main scopes for this tourist-smart destination technology-based relationship, namely (a) mobile technologies use, (b) data sharing for personalised experiences and (c) smart technologies for enhanced experiences.
\end{abstract}

Research limitations/implications: Convenience sampling was employed and the results of the study cannot be generalised to all millennial tourists. The research is a first approximation to the interrelationship between tourists and smart destinations.

Practical implications: Tourists' role and experiences mediated by ICTs are decisive in smart destinations. DMOs, through their policies and actions, ought to take into account the limited predisposition of tourists in employing mobile devices, sharing data and using smart technologies for their experiences. Privacy concerns appear to have special relevance for tourists, and therefore, for the future of smart destinations.

Originality/value: The findings offer relevant insights for smart destinations from a neglected angle hitherto, as they introduce several interesting nuances which don't match entirely the fast track taken by institutions, media and academia. This is critical for better understanding tourists in the current panorama, for DMOs and for the theoretical foundations of smart tourism. Besides, the exploratory data analysis reveals potential dimensions of millennials' behaviour which can be useful for further investigations.

Keywords: Smart tourism destinations; Smart tourism; Millennials; Generation Y; ICTs; Tourist behaviour 


\section{INTRODUCTION}

Smart Destinations (SDs) are described as those that employ a cutting-edge technological infrastructure to improve tourists' experiences and their own competitiveness (Buhalis \& Amaranggana, 2014; Del Chiappa \& Baggio, 2015; Xiang, Tussyadiah, \& Buhalis, 2015). This concept is gradually resulting in a new destination management approach shaped by technology, but also by other factors like new governance and management perspectives (Ivars-Baidal, Celdrán-Bernabeu, Mazón, \& Perles-Ivars, 2017), and an entirely developing network of digital businesses (Gretzel, Sigala, Xiang, \& Koo, 2015). Several countries such as Spain, South Korea or China, have embraced this new approach and are dedicating huge efforts and public resources to develop and apply the idea (Gretzel, Sigala et al., 2015; X. Wang, Li, Zhen, \& Zhang, 2016). The growing popularity of the SD is accompanied by an increasing but still limited literature production (Boes et al., 2015), and a great expectation by governments, media and private companies. This has made the concept a buzzword used carelessly by the multiple interested agents (Gretzel et al., 2015).). This has generated a notable hype around the concept, which may be far from destinations' reality and, especially, from tourists' reality.

On another side and in parallel to this, the use of Information and Communication Technologies (ICTs) by tourists has been greatly acknowledged, and well-studied from the more classical technology adoption studies based on TAM and UTAUT (Davis, 1989; Venkatesh, Morris, Davis, \& Davis, 2003) and their extensions, to more current schemes for understanding their use and impact on experiences (e.g. Wang, Xiang, \& Fesenmaier, 2014, 2016). However, literature concerning tourists' ICT perception and use on one hand, and smart destinations on the other hand, have followed separated paths, even though the intensive use of manifold technologies by visitors is a crucial pillar of SDs functioning. Besides, technology hasn't been examined from the tourists' perception of the specific uses which it may be given in the smart context. Smart tourism has uncritically assumed tourists want to use ICTs for multiple purposes, in every context, all the time, and that they wish to do so by interacting with the stakeholders in a dynamic and open way. In a nutshell, SDs have anticipated that tourists are 'smart' in the sense that they want to have a supper-connected experience. Nevertheless, this assumption has no strong empirical support. This way, the real alignment between the tourists' real perceptions and uses of ICTs, and what the smart destination expects from them in this regard, constitutes a major research gap (Buonincontri \& Micera, 2016; Gretzel, Reino, et al., 2015; X. Wang et al., 2016; Xiang \& Fesenmaier, 
2017). This paper contributes to acknowledge this neglected angle by testing these expectations with the reality represented by emergent and tech-savvy tourism demand.

This direction of demand is perfectly represented by the youngest and most digitalised population: 'Generation Y' or 'Millennials', who are well-known for their intensive use of ICTs (Xiang, Magnini, \& Fesenmaier, 2015). However, little is known about millennials' attitude and behaviour at destinations, although they are the market spending core of tomorrow (Kim, Xiang, \& Fesenmaier, 2015; Vukic et al., 2015). Their pioneering behaviour regarding new technologies could be even stronger in the case of university tourism students because of their current educational enrolment and interest in the travel sector. In fact, age, together with educational level, is frequently considered among the variables determining tourist behaviour and grouping (Pearce, 2005), and actively affect the technology use degree (Benckendorff, Sheldon, \& Fesenmaier, 2014). Therefore, the population under study in this paper, Spanish millennial tourism students, represents a cutting-edge and forward-thinking demand segment with special traits which is perfect for testing the response of prospective demand in front of the advent of SDs.

Thus, by acknowledging the above-mentioned research gaps, the objective of this paper is to contrast the great expectations placed on the smart destination as a theoretical management approach with the reality of this millennial and tech-savvy tourism demand. In other words, this study intends to know if the considerable expectation (hype) placed on the smart destination approach is justified by the current technology perception and use by tech-savvy tourism demand. This objective is specified in three research questions according to the critical technological dimensions for SDs:

RQ1. Is these millennial tourists' use of mobile technologies like expected by the smart destination as a theoretical approach?

RQ2. Are their preferences regarding data sharing in exchange for personalised experiences as open as the smart destination assumes?

RQ3. Do they perceive smart technologies as enablers of enhanced experiences like smart destinations anticipate?

In line with this, the present paper explores the main determinants or constructs of millennial tourists' behaviour. This is done by using exploratory factor analysis techniques that could be confirmed in future studies aimed to empirically establish the relationship between 
millennials' behaviour and smart destinations performance through, for example, structural equation modelling techniques.

By unifying a fragmented literature and taking the generational theory as a reference, this paper contributes with original perspectives to the study of tourism demand within a highly technological setting and helps to strengthen the theoretical foundations of smart tourism and destinations. The results evidence that the idealisation of the smart destination is still far from this tech-savvy tourists' reality in the use and perception of ICTs, at least for the moment. This poses notable implications for the understanding of tourists and smart destinations management, which are thoroughly discussed.

\section{LITERATURE REVIEW}

\subsection{Smart Destinations and Tourism Demand: Expectations for an ICT-based Relationship}

One of the biggest transformations tourism has ever faced is the impact of ICTs, which have completely reshaped not only the way the whole industry works and destinations operate (Buhalis \& Law, 2008), but also the tourist experience itself (Neuhofer, Buhalis, \& Ladkin, 2012; Tussyadiah \& Fesenmaier, 2009). Particularly critical landmarks in this process have been the advent of the smartphone and its effects over tourists' experiences (D. Wang et al., 2014; 2016), online review sites and their influence in decision-making (Book, Tanford, Montgomery, \& Love, 2015), or search engines and the impact of social media on communication between tourists and on their behaviour (Bigné, Andreu, Hernandez, \& Ruiz, 2016; Leung, Law, van Hoof, \& Buhalis, 2013).

Recent advancements like cloud computing, sensors and GPS widespread use, virtual and augmented reality, and the full adoption of social media and mobile technologies have pushed the emergence of smartness in tourism (Xiang \& Fesenmaier, 2017). Hence, the conceptualisation of destinations has evolved, and the SD has positioned itself as an adaptation of the destination notion to the revolution of the latest ICTs (Jovicic, 2016) and has emerged as a novel destination management approach (Ivars-Baidal et al., 2017). In this smart management approach, tourists occupy a central place and their relationship with the destination is articulated around some critical scopes in which their attitudes and behaviours are essential and several expectations are held, namely in: 
- Mobile technologies use (Gretzel, Sigala et al., 2015)

- Data sharing for personalised experiences (Buhalis \& Amaranggana, 2015; D. Wang, Li \& Li, 2013)

- Smart technologies for enhanced experiences (Gretzel, Werthner et al., 2015; Huang, Goo, Nam, \& Yoo, 2017).

2.1.1. Mobile technologies use. Mobile technologies have marked a turning point in the process of transformation which ICTs have meant for tourist experiences (Neuhofer et al., 2012; Wang et al., 2014, 2016). Combined with the influence of social media on consumer behaviour (Leung et al., 2013), and particularly on the communication and information exchange between tourists (Bigné et al., 2016), they are major drivers of change in tourist behaviour, together with the online reviews sites and other sources of electronic word-of-mouth (eWOM) (Book et al., 2015; Leung et al., 2015).

Smartphones and other mobile technologies such as smartwatches, smart glasses or wristbands (wearables) constitute a key pillars for the development of SDs, which expect these mobile technologies to be used by visitors for many purposes, during all the stages of the trip and to interact dynamically with all stakeholders in different scopes (Choe \& Fesenmaier, 2017; Gretzel, Werthner et al., 2015; X. Wang et al., 2016). These devices co-exist with the almost 'classical' mobile devices like laptops and digital cameras, and serve as a link between the tourist and the SD.

2.1.2. Data sharing for personalised experiences. One of the principal features of smart destinations is their ability to provide highly personalised experiences to tourists through the exploitation of their data (Buhalis \& Amaranggana, 2015). The use of intelligent systems necessarily involves the gathering of personal data, which may imply some privacy and security risks for tourists that they may not consider (Gretzel, 2011). As Gretzel, Sigala, et al. (2015) maintain, destinations and companies have assumed that tourists agree to share with them their activity and generated data without truly asking for their view. Therefore, it is expected that tourists in the SD will share different type of information with different stakeholders (i.e. DMOs and businesses) because they are looking for tailored experiences, but the level of acceptance of tourists of these premises is until now neglected. However, the different types of data available to share may generate distinct levels of trust and predisposition (Lee \& Cranage, 2011). Besides, according to Anuar \& Gretzel (2011), benefits for tourists (i.e. more personalised experiences) may mediate their privacy concerns together with other factors such as their 
age and travel experience, among other personal characteristics. In fact, age and familiarity with ICTs seem to be particularly relevant when it comes to different levels of privacy concern (Kuperus, 2016). The same could happen with the different nature of stakeholders with possible access to that data (public/mixed -DMOs- vs private companies operating at the destination), which may generate different trust levels (Anuar \& Gretzel, 2011).

2.1.3. Smart technologies for enhanced tourist experiences. Smart technologies (STs) are specific products and services which add value to tourist experiences in a concrete manner by fostering higher interaction, co-creation and personalisation levels (Neuhofer, Buhalis, \& Ladkin, 2015). Smart technology is also an ambiguous 'umbrella term' for many advanced technologies that take connectivity to a further step, including: sensors, Near-Field-Communication (NFC), augmented and virtual reality (AR \& VR), ubiquitous connectivity through $\mathrm{Wi}-\mathrm{Fi}$ and other networks and the use of mobile technologies, iBeacons and other smart tags, mobile apps, smart cards, latest generation websites and social networks, chatbots, etc. (Gretzel, Reino, et al., 2015; Huang et al., 2017). Many of these STs are dependent on DMOs implementation and promotion strategies. These different smart technologies serve as potential tourist experience enhancers (Neuhofer et al., 2015), particularly at the smart destination (Buonincontri \& Micera, 2016), and therefore it is expected that tourists will accept and use them as such, but it is ignored if tourists really perceive these technologies as capable of providing them with a better, smart experience.

In this point it becomes critical to assess the degree of alignment between the expectations held by this conceptual framework and the real perception and behaviours of tourists in these technological dimensions. This becomes even more important if this analysis is centred in the future spending core market that Gen Y represents, and particularly in the most ICT-skilled segment of this demand: tourism-interested and highly educated millennials.

\subsection{Millennials: The Digital Generation}

The generational theory was developed by sociologist Karl Mannheim and proposes cohort analysis to study societies and the different generations composing them (Mannheim, 1970). A generation is a group of people who have been born between certain years, and therefore, have risen experiencing the same sociocultural, political, and economic context (Solnet \& Hood, 2008). This has, supposedly, shaped common values, behaviours and attitudes towards 
multiple facets of life, such as work, family, consumption or leisure, and as part of the latter, also travelling (Leask, Fyall, \& Barron, 2013; Pendergast, 2010).

The young travellers of today coincide with Generation $\mathrm{Y}$, a share of demand that represents a rising flow of tourists with a growing spending capacity (Buffa, 2015; Cohen et al., 2014; Fyall, Leask, Barron, \& Ladkin, 2017; Nusair et al., 2011). This generation is also named as Millennials or the Digital/Net/Web Generation (Benckendorff, Moscardo, \& Pendergast, 2010). There is no consensus on their birth years, but they are more commonly referred as being born between 1982 and 2002 (Buffa, 2015; Kruger \& Saayman, 2015; Leask et al., 2013; Pendergast, 2010). This means a generation composed by approximately 1.743 million of potential travellers (World Bank, 2016), and the largest cohort in countries like the U.S. or Australia, generating 165.000 million of euros travelling yearly (Vukic et al., 2015). Nevertheless, knowledge regarding their behaviour as travellers is rather superficial (Benckendorff \& Moscardo, 2010; Huang \& Petrick, 2010; Solnet \& Hood, 2008), and mostly provided by company-based research.

As tourism demand, millennials have been described as new technologies 'early adopters'(Benckendorff et al., 2014). Besides, they use ICTs intensively for trip planning and employ diverse tools and channels to get as much information as possible (Xiang et al., 2015a). They are even known as 'digital natives' for their natural acceptance of technology as part of their lives (Cohen et al., 2014; Pendergast, 2010). Employing many online intermediaries, search engines and paying special attention to User-Generated Content (UGC) on social media, are argued to be specific traits of Generation Y (Kim et al., 2015). These facts would qualify them as 'the perfect tourist' for a smart destination. However, these general features haven't been actually contrasted with the specific expectations SDs hold in relation to tourists, while some evidence even seem to contradict the portrayal of digital natives as techno-addicts (e.g. Gretzel, Kennedy-Eden, \& Mistilis, 2012). Besides, most of research about Gen Y has been done in Anglophone countries (Cohen et al., 2014; Fyall et al., 2017), so knowledge about other regions millennials is missing. In this regard, the Spanish situation introduces some interesting nuances.

\subsubsection{The Spanish Millennials Case}

In Spain, millennials represent 10.49 million people (National Statistics Institute, 2016), but face huge challenges because their complicated incorporation to the labour market due to the economic crisis initiated in 2008. Apart from this precarious situation, Spain represents an 
especially interesting context for analysing emerging tourism demand in relation to the smart destination scenario. On one hand, Spanish young population are particularly early adopters of the latest technologies, as revealed by a recent telecom company Telefónica report: $98.8 \%$ use their smartphones to connect to the internet (aged 16-24), $44.5 \%$ of them uses regularly videochat to communicate, $50 \%$ uses the cloud to store information (aged 14-19), 52.4\% wishes to communicate to companies through instant message apps (aged 20-24) and a 79.5\% makes unplanned decisions related to leisure on real time thanks to information received through smartphone (aged 14-19). Apart from age, educational level becomes relevant in this regard, as internet users rank between $97.8 \%$ in the case of graduates and only $40.8 \%$ among people who only completed primary school (Fundación Telefónica, 2016). This demonstrates how, at least in the Spanish case, there is a notable gap in the use of ICTs in relation to the educational level. On the other hand, the country's government has developed a national project to foster the implementation of smart policies, and is leading a standardisation strategy for SDs (SEGITTUR, 2015). This makes the country a favourable context for investigations in the field.

\section{METHODS}

Initially, a thorough review of literature allowed identifying the three main technological dimensions or scopes relevant for smart destinations and tourists in their interrelationship, in which several premises were held. Having defined the possible variables to measure the attitude and behaviour in these three aspects, an online questionnaire was designed. This was created employing the software Qualtrics (C) and distributed to tourism students of four Spanish public universities during November and December 2016 through a generated linked distributed through the student-professor interaction platforms, offering the participants to be part of a draw to win a trip to a Spanish National Park. A total of 407 valid responses were collected (response rate of 35\%), from which a final sample of 358 corresponding to Spanish participants was used. The questionnaire was previously tested in a pilot research, and was refined according to the needs and problems detected. Due to the difficulty to establish a concrete total number for the population under study (Spanish millennial tourism students), and the legal limitations on obtaining personal data, a non-probabilistic sampling was employed. Millennial graduate and undergraduate tourism students were selected as target population because of their current formation, ability to use technologies, age and great interest in travel sector, which makes them the perfect example of highly ICT-involved 
tourists which could fulfil the expectations smart destinations hold. Furthermore, they represent part of a prospective demand segment with critical relevance for the future of tourism and can reflect trend-setting attitudes and behaviours regarding ICTs use and perception.

The questionnaire was structured in several blocks. After a filter question to discriminate the students who were born between 1982 and 2002 (millennials), the first block gathered data on mobile technologies use in travel context: types of devices used, purposes of use (adapted from D. Wang et al., 2014; 2016) and intensity of use through a five-point Likert scale. The use of mobile technologies in relation to specific situations/interactions in smart destinations (derived from literature: Buhalis \& Amaranggana, 2014; 2015; Gretzel, Sigala et al., 2015; Gretzel, Reino et al., 2015, among others) was tested through dichotomic choice (YES/NO). In the second block, respondents were asked to provide their preferences on data sharing (list of concrete items of different type data, adapted from Lee \& Cranage, 2011) in exchange for personalised experiences through dichotomous questions (YES/NO). In the following section, an extensive list of available smart technologies for destinations, based on previous research and smart tourism plans (Buonincontri \& Micera, 2016; INVAT·TUR \& IUIT, 2014; Ivars, Solsona \& Giner, 2016; Koo, Yoo, Lee, \& Zanker, 2016; SEGITTUR, 2015) was presented to participants. They were asked to assess on a Likert scale their perception of the potential of each of these smart technologies for enhancing their tourist experience. The last block collected personal demographic and economic data.

After the initial data exploration and the analysis of frequencies, an exploratory factor analysis was performed in SPSS software in order to detect the subjacent factors of analysed variables. Due to its exploratory nature, this factor analysis was carried out by extracting the principal axis factoring, without previously establishing the number of the factors. To let the possibility of correlations among extracted factors, an oblique Promax rotation with Kaiser normalisation was selected. Uniquely factors whose eigenvalue was greater than one and with at least two variables were retained. Finally, a minimum loading factor of 0.3 was considered to assign variables to each factor and to show the loading factor in tables.

\section{RESULTS}

Following the initial presentation of the participants' academic and socioeconomic traits, the results were weighted to give equal relevance to male and female answers and organised 
according to the three identified dimensions. To finish, an exploratory factor analysis to distil the possible explanation of some of the observed behaviours and attitudes is performed.

\subsection{Respondents' Profile}

In concordance to the usual proportion in the tourism education programmes, female students represent the majority of the sample (74.58\%), attending most of them the Degree in Tourism, although a significant part is enrolled in the Tourism and Business double degree, and a lesser share in the master level.

Table 1. Respondents' demographic and economic data

\begin{tabular}{|c|c|c|}
\hline & $n=$ & $\begin{array}{l}\text { Percentage } \\
\quad(\%)\end{array}$ \\
\hline \multicolumn{3}{|l|}{ Median age: 21.10} \\
\hline \multicolumn{3}{|l|}{ Gender } \\
\hline Total & 358 & 100 \\
\hline Female & 267 & 74.58 \\
\hline Male & 91 & 25.42 \\
\hline \multicolumn{3}{|l|}{ Studies type } \\
\hline Degree in Tourism & 242 & 67.60 \\
\hline Degree in Tourism + Business adm. & 93 & 25.98 \\
\hline Master in Tourism & 23 & 6.42 \\
\hline \multicolumn{3}{|l|}{ Total yearly income } \\
\hline$<3.000 €$ & 185 & 51.68 \\
\hline $3.000-6.000 €$ & 76 & 21.23 \\
\hline $6.001-9.000 €$ & 19 & 5.31 \\
\hline $9.001-12.000 €$ & 9 & 2.51 \\
\hline $12.001-15.000 €$ & 9 & 2.51 \\
\hline $15.001-18.000 €$ & 3 & 0.84 \\
\hline$>18.000 €$ & 3 & 0.84 \\
\hline _No answer & 54 & 15.08 \\
\hline \multicolumn{3}{|l|}{ Economic situation } \\
\hline -Receives family help & 318 & 88.83 \\
\hline -Receives scholarship & 122 & 34.08 \\
\hline -Receives scholarship and family help & 104 & 29.05 \\
\hline -Works regularly & 37 & 10.34 \\
\hline -Works sporadically & 151 & 42.18 \\
\hline $\begin{array}{c}\text {-No family help and no scholarship } \\
\text { (independent) }\end{array}$ & 22 & 6.15 \\
\hline
\end{tabular}


Despite their age (mean 21.10), the participants have already been at 5,10 countries on average, and declare to travel as much as two (26.82\%), three (15.64\%), four (12.29\%) or five and more times $(19.55 \%)$ per year. Their complicated economic situation is revealed by the fact that their yearly income falls mainly below $6.000 €$, and most of them are dependent on family help to develop their studies.

\subsection{Mobile Technologies Use}

Regarding mobile technologies, smartphone is without doubt the most used device while travelling by these millennial tourism students (97.21\%), surprisingly followed by digital camera (64.53\%), while laptops (31.56\%), GPS (25.70\%) and tablets (24.02\%) are less used, and wearables like smartwatches or google glasses are very unusual (1.12\%). The participants employ intensively (Quite and $A$ lot) these devices for destination information search $(93.56 \%)$, taking pictures or videos $(93.26 \%)$, talking to relatives $(86.83 \%)$, consulting maps or using GPS (84.07\%), sharing pictures and videos through social media $(70.79 \%)$, looking for reviews about businesses and specific tourist attractions $(63.69 \%$ and $68.35 \%$ respectively), but also for booking activities like tours, excursions or events $(54.21 \%)$ and translating words (47.82\%). However, only $12.08 \%$ of respondents use smartphone for paying and $22.91 \%$ for sharing their opinion on businesses and places.

Going in depth on their perception of the use of mobile technologies, several situations and interactions possible on the smart destination scenario were presented and participants were asked whether they would like to use their devices for each purpose. The results (Table 2) show that while they are highly open to receive tourist information, proposals and plans or discounts, and want to share their experience via their mobile devices, this demand is not willing to interact actively with the tourist office, with other tourists or to pay through these devices.

Table 2. Participants' willingness to use mobile technologies at destination for selected situations

\begin{tabular}{|c|c|c|}
\hline & Yes & Yes \\
$(n)$ & $(\%)$ \\
\hline Receiving information about tourist attractions and places & 320 & 89.3 \\
\hline Getting proposals for activities and new plans & 311 & 86.9 \\
\hline Receiving information about events on destination & 305 & 85.2 \\
\hline
\end{tabular}




\begin{tabular}{|c|c|c|}
\hline Sharing their experience with known people & 295 & 82.5 \\
\hline Getting discounts and offers & 291 & 81.4 \\
\hline Interacting with destination businesses & 208 & 58.1 \\
\hline Reviewing businesses and services & 170 & 47.4 \\
\hline Interacting with tourism office & 125 & 35 \\
\hline Interacting with other tourists & 117 & 32.6 \\
\hline Receiving personalised adverts & 89 & 24.8 \\
\hline Paying & 87 & 24.2 \\
\hline
\end{tabular}

These findings pose that millennials use smartphone intensively for manifold purposes during the different stages of their trips, but they don't use the most advanced mobile technologies for the moment and neither wish to interact all the time and for all the matters with the other stakeholders of destinations. These results partially blur the myth of all millennials as being highly open to interact through technology, as the smart destination expects, and draw a rather moderated wish to use mobile technology to mediate their tourist experience.

\subsection{Data Sharing for Personalised Experiences}

Respondents were asked to express their willingness to share their personal data in exchange for obtaining more personalised experiences.

Table 3. Respondents' willingness to share different personal data with tourism public and private organisations to obtain personalised experiences

\begin{tabular}{|l|c|c|}
\hline & $\begin{array}{c}\text { With private } \\
\text { companies } \\
(\% \text { Yes })\end{array}$ & $\begin{array}{c}\text { With public } \\
\text { agents } \\
(\% \text { Yes })\end{array}$ \\
\hline Age & 87.6 & 85.6 \\
\hline Hobbies and personal preferences & 77.6 & 72.8 \\
\hline Gender & 75.7 & 71.7 \\
\hline Nationality & 73.5 & 72.2 \\
\hline Name & 70 & 67.4 \\
\hline Relationship status & 23.3 & 21.4 \\
\hline Specific expenses in each place and service & 18.9 & 22.1 \\
\hline Sexual orientation & 17.7 & 18.8 \\
\hline Real time position & 11.7 & 16.5 \\
\hline Social media profiles & 10.7 & 10.9 \\
\hline Smartphone search history & 8.2 & 11.9 \\
\hline None & 3.1 & 4.3 \\
\hline
\end{tabular}


Findings (Table 3) show a clear difference between data which participants consider sensitive or not. The answers received by more personal matters: expenses, real time position, profiles on social media and smartphone search history, contrast with basic information like age, name, nationality or hobbies, which are happily ceded in exchange for more tailored experiences. Moreover, there is no significance difference in regard to the agent to whom they would prefer to cede this data (tourism public agent vs tourism private company). These findings indicate a complex attitude towards data sharing and threaten part of the functioning of the SD and the expected interaction with DMO and businesses. Context-aware marketing, the design of experiences based on information from social media profiles, or the intelligence derived from transaction data crossed with personal information are partly at stake.

\subsection{Smart Technologies: Experience Enhancement Capacity Perception}

With the aim of assessing the existing smart technologies or solutions that smart destinations propose to implement because of their potential for enhancing experiences, respondents were asked to provide their perception of the degree in which each smart technology could improve their experience as tourists. Results (Table 4) show that some smart technologies are highly appreciated by these tourists, while others are not perceived as 'experience enhancers'.

Table 4. Participants' perception of smart technologies as potential experience enhancers

\begin{tabular}{|c|c|}
\hline $\begin{array}{c}\text { In which degree do you think each of the following smart } \\
\text { technologies can improve your experience as a tourist? }\end{array}$ & Quite + \\
\hline $\begin{array}{c}\text { Destination official website in several languages, with rich } \\
\text { digital content and direct booking possibilities }\end{array}$ & 92.6 \\
\hline Public free Wi-Fi & 85.2 \\
\hline Interactive tourism office with Wi-Fi, touchscreens and \\
dynamic information & 84.1 \\
\hline Multipurpose tourism card & 83.6 \\
\hline Official destination accounts on social media & 73.6 \\
\hline Official destination App & 73.3 \\
\hline Destination central booking platform & 63.9 \\
\hline Sensor-derived information about traffic, pollution, noise ... & 59.6 \\
\hline Touchscreens on destination streets & 57.3 \\
\hline Video guides & 49.8 \\
\hline Payment through smartphone & 46.1 \\
\hline Augmented reality & 42.3 \\
\hline QR codes & 41.3 \\
\hline Location-based information (through iBeacons, Bluetooth) & 40.9 \\
\hline
\end{tabular}




\begin{tabular}{|c|c|}
\hline Virtual reality & 39.4 \\
\hline Destination online assistance (skype) & 37 \\
\hline Videomapping and holograms & 32.3 \\
\hline Chatbots & 22.6 \\
\hline Wearable technologies & 21.9 \\
\hline Electronic money (bitcoin, etc.) & 21.7 \\
\hline Gamification & 20.8 \\
\hline
\end{tabular}

Thus, while a last generation official website, public Wi-Fi at destination, an interactive tourism office, an official app and profiles of the destination on social media or a multipurpose smart card are highly valued, others don't seem to have this capacity to date (gamification, wearables, electronic money...). This outcome suggests a progressive and moderated assumption of technologies for enhancing experiences by these educated millennials and puts into question some of the high expectations placed on many advancements which aren't perceived as real value generators by this tech-savvy demand.

\subsection{Attitudes and Behaviour Explanation}

As explained in the methodological section, an exploratory factor analysis has been performed over those matters that, even being measured as categorical variables through a Likert scale, can be assumed as having an underlying continuous variable. Three matters have been included in the exploratory analysis.

With regard to the question ' $¿$ In which degree do you use the selected mobile technologies [previously chosen in the prior question] for each of the following functions?', ten possible uses of these technologies were proposed (see section 4.2.), which had to be assessed from 1 to (not at all) to 5 (a lot) in a Likert scale. After checking the feasibility of applying the technique (KMO 0.680 and Bartlett's Test p-value 0.000), it is observed that using the eigenvalue greater than one extraction criteria, four basic factors emerge that are capable of explaining $61 \%$ of the variance. In this solution, only one factor (factor one) that matches with the variables 'looking for opinions or reviews about specific businesses' and 'looking for opinions and reviews about tourist attractions' has a clear interpretation: 'Businesses and places information search'. The other obtained factors present a mix of variables that are difficult to interpret or include only one variable and their reliability measured trough their Cronbach's Alpha is low. Thus, a solution with two factors (Table 5) has been forced. The first factor, which explains $27.20 \%$ of the variance, is the same that in the four factors 
solution and can be clearly matched, as in the previous case, with the 'businesses and places information search' function, as it gathers in the same function 'looking for opinions or reviews about specific businesses', 'looking for opinions and reviews about tourist attractions' and in a lower level 'searching for general information about the destination'. The second factor, which explains $13.21 \%$, could be identified as other more generic or 'social, transactional and other uses' of mobile technologies with an accent in the social sharing of experience -the variable that loads more this factor is precisely 'sharing pictures and videos on social media'-, because the other variables such as 'paying through smartphone', 'talking to relatives', 'searching for general information about the destination' and 'booking activities', load lower in the factor. The analysis of factor correlation matrix shows that both factors are correlated (0.38) and the reliability analysis reveals that reliability level of factors is acceptable with a Cronbach's Alpha of 0.69 for the first factor and 0.67 for the second. Thus, the results point out that these tourists, in general, use mobile technology for two basic purposes: 1) searching for information and opinions about businesses and attractions operating at destinations, and for 2) social and transactional purposes, especially to share their tourist experience.

Table 5. Exploratory factor analysis for uses of mobile technologies

\begin{tabular}{|c|c|c|}
\hline \multicolumn{3}{|c|}{ Pattern Matrix $^{\mathrm{a}}$} \\
\hline & \multicolumn{2}{|c|}{ Factor } \\
\hline & $\begin{array}{l}\text { Businesses and places } \\
\text { information search }\end{array}$ & $\begin{array}{l}\text { Social, transactional } \\
\text { and other uses }\end{array}$ \\
\hline $\begin{array}{l}\text { Searching for general information about } \\
\text { the destination }\end{array}$ & 0.346 & \\
\hline Booking activities & & 0.312 \\
\hline $\begin{array}{l}\text { Looking for opinions or reviews about } \\
\text { specific businesses }\end{array}$ & 0.900 & \\
\hline $\begin{array}{l}\text { Looking for opinions and reviews about } \\
\text { tourist attractions }\end{array}$ & 0.761 & \\
\hline Taking pictures & & 0.305 \\
\hline Using the GPS & & 0.316 \\
\hline $\begin{array}{l}\text { Sharing pictures and videos on social } \\
\text { media }\end{array}$ & & 0.713 \\
\hline Talking to relatives' & & 0.456 \\
\hline Sharing opinion on places and services & & 0.382 \\
\hline Paying through smartphone' & & 0.386 \\
\hline Translating words & & 0.461 \\
\hline
\end{tabular}


${ }^{\mathrm{a} E x t r a c t i o n}$ method: Principal axis factoring. Rotation method: Promax with Kaiser Normalization.

Moreover, the different technologies that could be implemented in SD by a DMO were analysed. A total of 21 smart technologies were presented to participants to assess them in a Likert scale from 0 (Not at all) to 5 (A lot), according to the degree they thought they could enhance their tourist experience. Again, the data are suitable for the analysis (KMO 0.85 and Bartlett's test p-value 0.000), getting in this case five factors explaining $57 \%$ of the variance. Its interpretation results simple (see Table 6). The first factor, which explains $31 \%$ of the variance, can be understood as the 'well-established technology for tourism information', as it gathers the 'destination official web', 'free public Wi-Fi' and destination 'official app' and has a reliability (measured through his Cronbach's Alpha) of 0.71. A second factor clarifying $10.24 \%$ of the variance is associated with 'online communication with the destination', including the items 'tourism office online assistance', 'QR codes' and 'video guides' (reliability 0.59). A third factor, explaining $6 \%$ of the variance is associated with the 'innovative technology in tourism' as it is positively associated with the items 'wearables', 'electronic money' and 'gamification' (reliability (0.75). Also, a fourth factor explaining the $5.21 \%$ of the variance is linked with 'new visualisation technology' as it is positively associated with the items 'augmented reality', 'virtual reality' (reliability 0.78). Lastly, the fifth factor, which explains another $5 \%$ of the variance, is related with the 'technological infostructure \& social media of DMO' as it includes 'touchscreens in the office' and 'interactive tourism office with Wi-Fi' (reliability 0.62 ). The analysis of factor correlation matrix (Table 7) shows that practically all factors are correlated and only the factors 'Wellestablished technology for tourism information' and 'Innovative technology in tourism' seem to appear independent, pointing out that within millennial tourists there could be a 'classic' segment less concerned about, or valuing less, emerging technologies as potential catalysts of their tourist experience.

Table 6. Exploratory factor analysis for preferred smart technologies

\begin{tabular}{|c|c|c|c|c|c|}
\hline \multicolumn{2}{|c|}{ Pattern Matrix } \\
\cline { 2 - 5 } & $\begin{array}{c}\text { Well- } \\
\text { established } \\
\text { technology for } \\
\text { tourism } \\
\text { information }\end{array}$ & $\begin{array}{c}\text { Online } \\
\text { communicat } \\
\text { ion with } \\
\text { destination } \\
\text { Touchscreens }\end{array}$ & $\begin{array}{c}\text { Innovative } \\
\text { in tourism }\end{array}$ & $\begin{array}{c}\text { New } \\
\text { visualisation } \\
\text { technology }\end{array}$ & $\begin{array}{c}\text { Technological } \\
\text { infostructure } \\
\& \text { social } \\
\text { media of } \\
\text { DMO }\end{array}$ \\
\hline $\begin{array}{c}\text { Destination official } \\
\text { accounts on social media }\end{array}$ & & & & 0.715 \\
\hline
\end{tabular}




\begin{tabular}{|c|c|c|c|c|c|}
\hline Interactive tourism office & & & & & 0.561 \\
\hline Destination official web & 0.532 & & & & \\
\hline $\begin{array}{l}\text { Tourism office online } \\
\text { assistance }\end{array}$ & & 0.552 & & & \\
\hline QR codes & & 0.586 & & & \\
\hline Free public Wi-Fi & 0.877 & & & & \\
\hline Official app & 0.398 & 0.339 & & & \\
\hline Video guides & & 0.525 & & & \\
\hline Augmented Reality & & & & 0.954 & \\
\hline $\begin{array}{l}\text { Destination official } \\
\text { booking platform }\end{array}$ & & 0.413 & & & \\
\hline \multicolumn{6}{|l|}{$\begin{array}{c}\text { Location-based } \\
\text { information (iBeacons. } \\
\text { Bluetooth) }\end{array}$} \\
\hline $\begin{array}{l}\text { Payment through } \\
\text { smartphone }\end{array}$ & & 0.499 & 0.414 & & \\
\hline Wearables & & & 0.803 & & \\
\hline Electronic money & & & 0.628 & & \\
\hline Video mapping & & & & 0.457 & \\
\hline \multicolumn{6}{|l|}{ Tourist cards } \\
\hline \multicolumn{6}{|l|}{$\begin{array}{l}\text { Information about traffic. } \\
\text { pollution and noise }\end{array}$} \\
\hline Virtual reality & & & & 0.541 & \\
\hline Chatbots & & 0.420 & & & \\
\hline Gamification & & & 0.531 & & \\
\hline
\end{tabular}

${ }^{a}$ Extraction method: Principal axis factoring. Rotation method: Promax with Kaiser Normalization.

Table 7. Factor correlation matrix for preferred smart technologies

\begin{tabular}{|c|c|c|c|c|c|}
\hline \multirow{2}{*}{} & \multicolumn{4}{|c|}{ Component } & 年 \\
\cline { 2 - 6 } & $\begin{array}{c}\text { Well-established } \\
\text { technology for } \\
\text { tourism information }\end{array}$ & $\begin{array}{c}\text { Online } \\
\text { communica } \\
\text { tion with } \\
\text { destination }\end{array}$ & $\begin{array}{c}\text { Innovative } \\
\text { technology } \\
\text { in tourism }\end{array}$ & $\begin{array}{c}\text { New } \\
\text { visualisation } \\
\text { technology }\end{array}$ & $\begin{array}{c}\text { Technological } \\
\text { infostructure \& } \\
\text { social media of } \\
\text { DMO }\end{array}$ \\
\hline $\begin{array}{c}\text { Well-established } \\
\text { technology for } \\
\text { tourism information }\end{array}$ & 1.000 & $\mathbf{0 . 5 9 3}$ & 0.158 & $\mathbf{0 . 3 3 3}$ & $\mathbf{0 . 4 8 5}$ \\
\hline $\begin{array}{c}\text { Online } \\
\text { communication with } \\
\text { destination }\end{array}$ & 1.000 & $\mathbf{0 . 4 9 3}$ & $\mathbf{0 . 5 2 8}$ & $\mathbf{0 . 5 6 9}$ \\
\hline
\end{tabular}




\begin{tabular}{|c|c|c|c|c|}
\hline $\begin{array}{c}\text { Innovative } \\
\text { technology in } \\
\text { tourism }\end{array}$ & & 1.000 & $\mathbf{0 . 5 6 3}$ & $\mathbf{0 . 4 1 6}$ \\
\hline $\begin{array}{c}\text { New visualisation } \\
\text { technology }\end{array}$ & & & 1.000 & $\mathbf{0 . 5 2 9}$ \\
\hline $\begin{array}{c}\text { Technological } \\
\text { infostructure \& } \\
\text { social media of } \\
\text { DMO }\end{array}$ & & & & 1.000 \\
\hline
\end{tabular}

Bold: correlations exceeding the Tabachnick \& Fiddell (2007) threshold

\section{DISCUSSION AND CONCLUSION}

The aim of this paper was to contrast the reality which young and allegedly tech-savvy tourists represent, with the theoretical expectations and hype created around SDs. This has been done through an examination of the attitude and behaviour of Spanish millennial tourism students in relation to three technological scopes which are crucial for understanding their response to smart destinations expectations and functioning. The findings indicate that there is a gap between the assumptions and hopes of the smart destination and a young, ICT-skilled and educated demand behaviour which is evolving rapidly, but still lagging behind with regard to the high expectations held in the theoretical propositions. Thus, answering to the formulated research questions, the results indicate that: (1) These millennial tourists' use of mobile technologies is intensive and diverse in functions in all trip stages. However, they still show a limited willingness to use these technologies for interacting with other stakeholders dynamically. (2) Their data sharing attitude is twofold: they wish to share some general data but not other more personal which smart destinations expect to use for a higher personalisation of their experiences. (3) Their perception of smart technologies as catalysts of their experiences shows again a dual situation in which they embrace some STs, while other more innovative technologies, key for SDs development, aren't equally perceived.

These findings potentially jeopardise smart destinations projects heavily driven by institutions, which is common in Spain (Ivars-Baidal et al., 2017), as the results could indicate that quest for SDs responds more to political and place marketing strategies rather than to a real push by demand. Furthermore, the results call into question part of smart destinations theoretical propositions, and also the existence today of a young batch of tourists who base most of their experiences on ICTs. This is in line with previous findings which indicated a limited predisposition of digital natives to use ICTs and a critical position towards technology 
interference in their trips (Gretzel et al., 2012). In general, this paper's findings can also be interpreted as millennials' need to 'disconnect' from technology in certain moments and contexts, thus reflecting an increasingly recognised preference of tourists in an era of ubiquitous connectedness (Dickinson, Hibbert, \& Filimonau, 2016). However, a deeper discussion of these matters is needed at this point.

First, regarding mobile technologies, the findings differ from previous studies by taking the already acknowledged widespread use of smartphones further. This revealed interesting nuances that demystify the image of all the millennials as 'always ready' for using their mobile technologies for any matter. Yes, millennials use smartphones for manifold purposes and through different stages of the trip, which is in line with previous research (Hahm et al., 2008; Kim et al., 2015; Nusair et al., 2011; Pendergast, 2010; Xiang, Magnini, et al., 2015), but in the case of this sample, they don't wish to use these tools, for the moment, for issues like paying, interacting with the tourist office and with other tourists dynamically, or receiving personalised offerings. Furthermore, wearables are still marginal, and surprisingly, digital cameras seem to 'survive'. This partly contradicts the principles and expectations of the SD and its relationship with tourists, in which a very advanced use of mobile technologies is supposed to play a crucial role (X. Wang et al., 2016; Choe \& Fesenmaier, 2017).

Second, concerning privacy, a new understanding of the relationship between different types of data to be ceded and the agent with whom these millennials would be more conformable sharing it, has revealed stimulating results. There seems to be a dichotomy in their predisposition to share different types of data depending on the specific nature of data: basic information (age, nationality, sex) is happily shared, but the participants prefer to keep for themselves more delicate personal information (search history, real time position, social media profiles, etc.). This suggests possible limitations to the interconnectedness and data exchange that the SD anticipates, while also calls for deeper examination. The results are aligned with Anuar \& Gretzel's (2011) proposition that different contexts and perception of the potential benefits of sharing may influence privacy concerns extent, and also with Buhalis and Amaranggana's (2015) in that privacy is a main issue among tourists in SDs. Thus, although privacy is a notable issue when using technologies for all general users (Huang et al., 2017), there seems to be a particularly high awareness among millennial tourists (Kuperus, 2016). However, surprisingly, results haven't shown any significant difference in the predisposition to share data with public agents or private companies. Both are equally trusted. These results extend the until now very limited knowledge of this matter in the smart 
destination setting (Buhalis \& Amaranggana, 2015) and may help to better delineate the pressing issue of data governance in smart tourism (Gretzel, Sigala et al., 2015), suggesting furthermore that privacy could be one of the triggers of tourists' wish to disconnect (Dickinson et al., 2016).

Third, while smart technologies are a concept still under construction and a vague 'umbrella term', previous contributions had been dedicated to comprehending the influence of concrete STs, their adoption in a phase of the trip, their influence over decision-making or tourist experience (e.g. Buonincontri \& Micera, 2016; Huang et al., 2017; Neuhofer et al., 2015). Nevertheless, this paper has introduced more shades and demonstrated that some highly anticipated solutions by literature on smart tourism (gamification, use of electronic money or chatbots) don't seem for the moment to enrich much the experience, at least for this techsavvy young demand. This challenges SDs trust in some of these STs and many efforts of real destinations in this direction.

To sum up, figure 1 offers a brief but systematic vision of the findings and reflects the used structure, which can serve as base for further explorations with different demand segments.

Figure 1. SDs and tech-savvy Spanish millennials: key findings

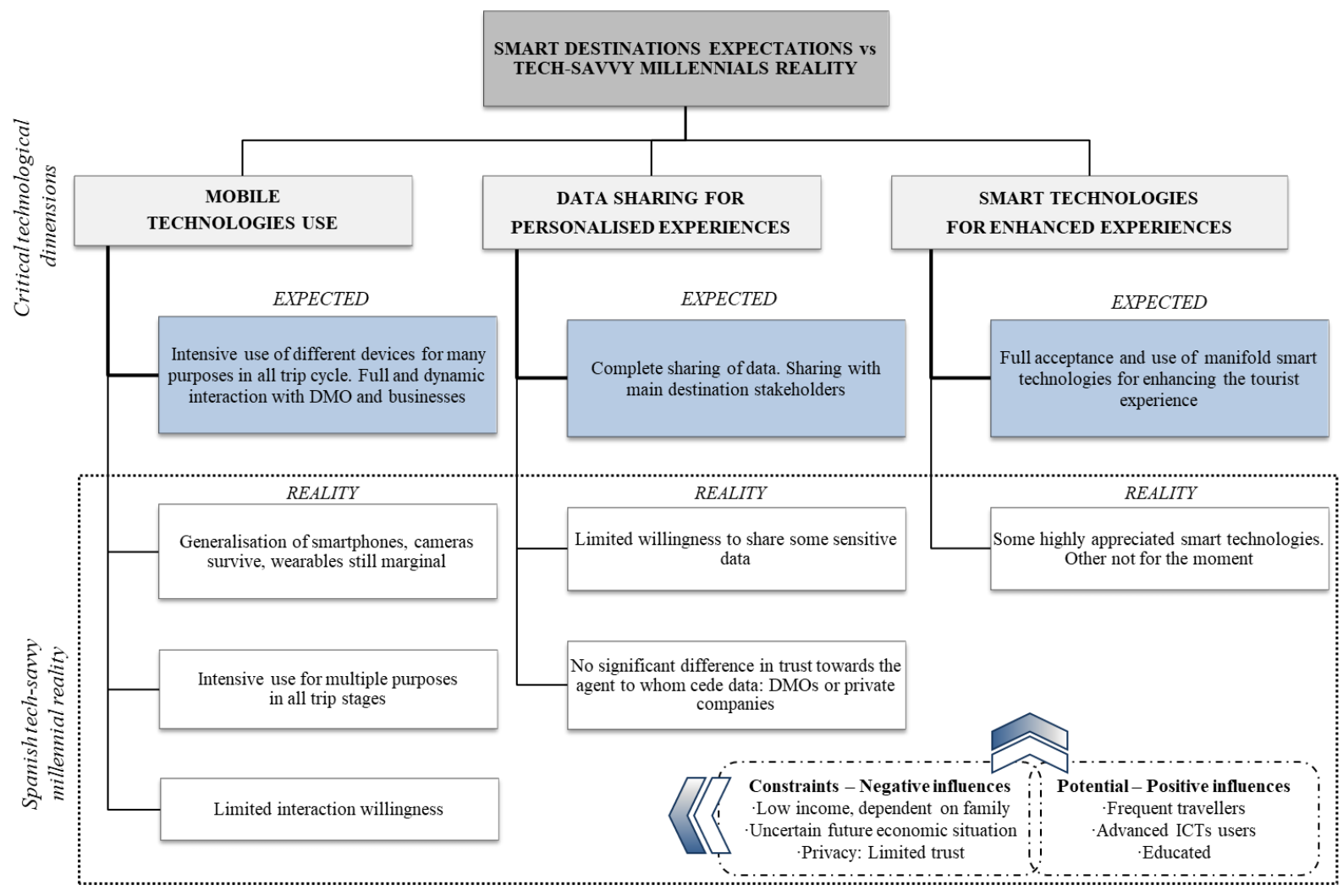


However, although reality and expectations don't match completely yet, the analysis of this interrelationship in the smart destination reveals some evidence (mobile devices complete adoption, openness to share certain data, acceptance of many smart technologies as experience enhancers...) that suggest the progressive emergence of a tourist who gradually adapts to smart destinations functioning: the smart tourist. In line with this, a new role of tourists within destinations emerges as technology evolves and transforms the functions visitors perform and how they relate to the increasingly complex smart business ecosystem. The results shed some light on how tourists and smart destinations will cope with each other in a highly changing environment and how this new relationship can evolve as the assimilation and use of smart technologies grow and they become a key element in smart tourists' experiences. In any case, it is critical for destinations to understand and adapt to this digital generation of tourists and their future evolution (Gretzel et al., 2012) in a technological ecosystem in which travellers' needs are the industry motto and ICTs develop faster and faster (Benckendorff et al., 2014).

\section{IMPLICATIONS}

\subsection{Contribution to literature}

The analysis of the Spanish university millennials' behaviour and preferences has confirmed a generalised use of ICTs by this segment, but also evidences a long way for this demand until it meets the expectations of smart destinations in this regard. However, the adoption of some ICTs may rapidly accelerate in the next years and change even more the panorama for destinations management. Still, it seems clear that the impact of technologies is already drawing a new scenario for destinations, a shift which has been captured by the new smart destination concept (Gretzel, Sigala, et al., 2015; Ivars et al., 2016, 2017; Jovicic, 2016). Nevertheless, the implications of these changes for tourists and their role needed to be further acknowledged. By doing so, this paper has addressed some of the identified pending issues by Gretzel, Werthner et al. (2015): privacy, trust in smart technologies and enjoyment of technology-enhanced experiences. This analysis hadn't been undertaken until now and opens many theoretical perspectives, contributing to the ongoing debate.

The evolution of tourists' behaviour is a key factor to interpret the new role of DMOs in the smart tourism ecosystem and helps in avoiding risks while taking advantage of emerging 
opportunities. All the stages of the tourism journey (from the inspiration to the post-travel phase) are mediated by technology and digital players (OTAs, gatekeepers, social media, etc.), permanently reshaping the relationship with tourists and the tourism value chain. This paper contributes to better understanding the perception and use of technologies by tourists, showing how essential functions of DMOs (information, marketing, destination intelligence...) should be redesigned to be adapted to the smart ecosystem. It also contributes to identifying the priorities for smart solutions dependent on DMO implementation, as a source of experience enhancement and competitive advantage. Therefore, a better knowledge of demand guides the DMO in the management of the hype-cycle of smart destinations.

Another important matter is to define the geographical scale of the smart destination. As Gretzel, Werthner et al. (2015) argue, the destination is a piece of the broader global smart tourism ecosystem, in which many intertwined players (OTAs, online travel communities, meta-searchers) are redefining the traditional roles. The influence of 'external' actors over destinations is not new. However, in this smart setting this is more intense and diverse in many essential aspects, such as commercialisation. This forces destinations to adapt to a new panorama in which they lose control over tourist activity in their territory and they can't seize the connected and independent tourist within a complex digital ecosystem. In this ecosystem it is extremely relevant to establish the place destinations occupy from new analysis approaches. Destinations management will be more ICT and data-based, a situation which could increase destinations dependence on the agents who accumulate and explode these data (telecom companies, banks or social media platforms). As it happens with the smart city, it is essential to perform a critical analysis of the winners and the losers of the smart destination, which hasn't been undertaken yet.

A needed analysis perspective is the evolution of technology and the new possibilities it opens for destinations. Nonetheless, this research has demonstrated a gap between the expectations placed on smart solutions and technologies and the reality of part of demand, which recommends putting the tourist in the centre and advises against purely technological proposals. In line with this, studying millennial generation will help to advance in this direction and to forecast scenarios.

\subsection{Managerial implications}

Unlike other studies devoted to concrete technologies, the analysis of a wide number of technological solutions performed in this research allows to distil recommendations for 
destinations management. In front of the avalanche of new technologies, and acknowledging their needs, capacities and resources, destinations should be selective in their actions.

First, mobile technologies should be prioritised while taking into account users' preferences. The manifold purposes for which mobile technologies can be used, together with the growing new applications, gives them a relevant place in smart destinations. The real impact on experiences of advancements like AR or VR will depend on their integration with smartphones. As results suggest, information, promotion and selling processes will move towards mobile world progressively, but this shift will have to adapt to the limited wish of part of millennials to use mobile technologies for determined purposes and situations.

Second, the development of smart solutions linked to the personalisation of experiences, will face barriers in obtaining some data. Spanish educated millennials seem reluctant to share certain type of information and don't discriminate public from private interests. This indicates that DMOs aren't seen as more transparent or trustworthy agents. DMOs should make an effort in building this trust, which would improve tourists' predisposition towards interacting and co-creating with them. However, more research regarding tourists' privacy concerns is needed to better shape these services that will enable further personalisation.

From an applied perspective, the results suggest DMOs should focus on some technologies which may not be the most showy, but render a clear benefit for tourists. A cost-benefit analysis should also guide this implementation. The findings recommend implementing technologies already successful and widespread: A dynamic, last generation official website, public Wi-Fi, modern interactive smart tourism office, a smart card, a useful app for smartphones or constantly updated destination profiles on social media.

In conclusion, the tourist-centred perspective taken in this research avoids the identification of the smart destination concept with the technological solutionism. It is a matter of how and for what tourists use technology, to adapt the smart destination strategy to their needs and to create a collaborative framework in which technology becomes a powerful tool for increasing visitor satisfaction and management efficiency. Tourists are going smart, but maybe slower than expected. They need to be the centre of smart destinations policies or this approach will definitively fail. 


\section{LIMITATIONS AND FUTURE RESEARCH}

As an initial step, the current research presents several limitations. First, because of the established objectives, the sample only encompassed university tourism students, but it would be highly interesting to be able to generalise the current results to students outside tourism programmes, completing a vision for a well-formed generation. A survey among all the Spanish millennials, regardless of their educational level, would provide enormously enriching insights. The difficulties to perform a completely random sampling makes this challenge a big one. Additionally, although the presented results reveal almost a 'forecast' of what the future demand for SD could look like, most of tourism demand is still composed by previous generations (baby boomers, silent generation...). These may be less responsive regarding what the smart destination requires from them. The current use of mobile technologies, willingness of tourists to share their data and perception of technologies will evolve in the next years, so there is a need to develop longitudinal studies. The conducted data analysis and obtained results don't intend to be confirmatory or generalisable, but rather to explore new dimensions of tourists' centrality in smart destinations, and therefore will need to be validated in different contexts and segments. Moreover, further conceptualisations of SDs could imply the research of other variables not considered here, but equally important, like sustainability or accessibility, for instance. The inclusion of other stakeholders in relation to the smart tourism ecosystem as depicted by Gretzel, Werthner et al. (2015), could bring to surface different outcomes and foster more critical perspectives.

Acknowledgements: Research carried out within the project 'Analysis of planning processes applied to smart cities and smart tourism destinations. Balance and methodological proposal for tourist spaces: Smart Tourism Planning' (CSO2017-82592-R) under the Spanish National R\&D\&I Plan and Grant no. BES-2015-073909, funded by the Ministry of Economy, Industry and Competitiveness

\section{REFERENCES}

Anuar, F. I., \& Gretzel, U. (2011). Privacy Concerns in the Context of Location-Based Services for Tourism. In ENTER 2011 Conference (short paper), Innsbruck (Austria), January 26-28. Retrieved from http://ertr.tamu.edu/files/2013/02/13.pdf

Benckendorff, P. J., Sheldon, P. J., \& Fesenmaier, D. R. (2014). Tourism Information Technology (2nd Ed.). Wallingford: CABI.

Benckendorff, P., \& Moscardo, G. (2010). Understanding Generation-Y Tourists: Managing the Risk and Change Associated with a New Emerging Market. In P. Benckendorff, G. Moscardo, \& D. Pendergast (Eds.), Tourism and Generation Y (pp. 38-46). Wallingford: CABI.

Benckendorff, P., Moscardo, G., \& Pendergast, D. (2010). Introduction. In P. Benckendorff, G. Moscardo, \& D. Pendergast (Eds.), Tourism and Generation $Y$. Wallingford: CABI.

Bigné, E., Andreu, L., Hernandez, B., \& Ruiz, C. (2016). The impact of social media and offline influences on consumer behaviour. An analysis of the low-cost airline industry. Current Issues in Tourism, 1-19. http://dx.doi.org/10.1080/13683500.2015.1126236 
Boes, K., Buhalis, D., \& Inversini, A. (2015). Conceptualising Smart Tourism Destination Dimensions. In I. Tussyadiah \& A. Inversini (Eds.), Information and Communication Technologies in Tourism 2015 (pp. 391-403). Cham: Springer. http://doi.org/10.1016/S0160-7383(01)00012-3

Book, L. A., Tanford, S., Montgomery, R., \& Love, C. (2015). Online Traveler Reviews as Social Influence: Price is no longer king. Journal of Hospitality \& Tourism Research, 1-31. https://doi.org/10.1177/1096348015597029

Buffa, F. (2015). Young tourists and sustainability. Profiles, attitudes, and implications for destination strategies. Sustainability, 7(10), 14042-14062. http://doi.org/10.3390/su71014042

Buhalis, D., \& Amaranggana, A. (2014). Smart tourism destinations. In Z. Xiang \& I. Tussyadiah (Eds.), Information and Communication Technologies in Tourism 2014 (pp. 553-564). Cham: Springer. http://doi.org/10.1007/978-3-31903973-2

Buhalis, D., \& Amaranggana, A. (2015). Smart Tourism Destinations Enhancing Tourism Experience Through Personalisation of Services. In I. Tussyadiah \& A. Inversini (Eds.), Information and Communication Technologies in Tourism 2015 (pp. 377-389). Cham: Springer.

Buhalis, D., \& Law, R. (2008). Progress in information technology and tourism management: 20 years on and 10 years after the Internet-The state of eTourism research. Tourism Management, 29(4), 609-623. http://doi.org/10.1016/j.tourman.2008.01.005

Buonincontri, P., \& Micera, R. (2016). The experience co-creation in smart tourism destinations: a multiple case analysis of European destinations. Information Technology \& Tourism, 16(3), 285-315. http://doi.org/10.1007/s40558-016-00605

Choe, Y., \& Fesenmaier, D. R. (2017). The Quantified Traveler: Implications for Smart Tourism Development. In Z. Xiang \& D. R. Fesenmaier (Eds.), Analytics in Smart Tourism Design (pp. 65-77). Switzerland: Springer.

Cohen, S. A., Prayag, G., \& Moital, M. (2014). Consumer behaviour in tourism: Concepts, influences and opportunities. Current Issues in Tourism, 17(10), 1872-909. http://doi.org/10.1080/13683500.2013.850064

Davis, F. D. (1989). Perceived Usefulness, Perceived Ease of Use, and User Acceptance of Information Technology. MIS Quarterly, 13(3), 319-340. https://doi.org/DOI: 10.2307/249008

Del Chiappa, G., \& Baggio, R. (2015). Knowledge transfer in smart tourism destinations: Analyzing the effects of a network structure. Journal of Destination Marketing \& Management, 30(10), 1757-1771. http://doi.org/10.1016/j.jdmm.2015.02.001

Dickinson, J. E., Hibbert, J. F., \& Filimonau, V. (2016). Mobile technology and the tourist experience: (Dis)connection at the campsite. Tourism Management, 57, 193-201. http://doi.org/10.1016/j.tourman.2016.06.005

Fundación Telefónica. (2016). La sociedad de la Información en España 2016. Retrieved from https://www.fundaciontelefonica.com/arte_cultura/sociedad-de-la-informacion/informe-sie-espana-2016/

Fyall, A., Leask, A., Barron, P., \& Ladkin, A. (2017). Managing Asian attractions, Generation Y and face. Journal of Hospitality and Tourism Management, 32, 35-44. http://doi.org/10.1016/j.jhtm.2017.04.006

Gretzel, U. (2011). Intelligent systems in tourism. A Social Science Perspective. Annals of Tourism Research, 38(3), 757779. http://doi.org/10.1016/j.annals.2011.04.014

Gretzel, U., Kennedy-Eden, H., \& Mistilis, N. (2012). Travel Information Search Behaviour of Digital Natives. In The new golden age of tourism and hospitality. CAUTHE conference (pp. 190-193). Melbourne.

Gretzel, U., Reino, S., Kopera, S., \& Koo, C. (2015). Smart Tourism Challenges. Journal of Tourism, 16(1), 41-47. http://doi.org/10.1108/JTF-12-2014-0023

Gretzel, U., Sigala, M., Xiang, Z., \& Koo, C. (2015). Smart tourism: foundations and developments. Electronic Markets, 25(3), 179-188. http://doi.org/10.1007/s12525-015-0196-8

Gretzel, U., Werthner, H., Koo, C., \& Lamsfus, C. (2015). Conceptual foundations for understanding smart tourism ecosystems. Computers in Human Behavior, 50, 558-563. http://doi.org/10.1016/j.chb.2015.03.043

Hahm, J., Upchurch, R., \& Wang, Y. (2008). Millennial students, movies, and tourism. Tourism Analysis, 13(2), $189-204$. http://doi.org/10.3727/108354208785664229

Huang, C. D., Goo, J., Nam, K., \& Yoo, C. W. (2017). Smart Tourism Technologies in Travel Planning: The Role of Exploration and Exploitation. Information \& Management, (In press). http://doi.org/10.1016/j.im.2016.11.010

Huang, Y.C., \& Petrick, J. F. (2010). Generation Y's Travel Behaviours: a Comparison with Baby Boomers and Generation X. In P. Benckendorff, G. Moscardo, \& D. Pendergast (Eds.), Tourism and Generation $Y$ (pp. 27-37). Wallingford: CABI.

INVAT·TUR \& IUIT. (2014). Manual Operativo para la configuración de Destinos Turísticos Inteligentes. Retrieved from http://www.slideshare.net/invattur/manual-operativo-para-la-configuracin-de-destinos-inteligentes

Ivars, J. A., Solsona, F. J., \& Giner, D. (2016). Gestión turística y tecnologías de la información y la comunicación (TIC): El nuevo enfoque de los destinos inteligentes. Documents d'Anàlisi Geogràfica, 62(2), 327-346. http://doi.org/10.5565/rev/dag.285

Ivars-Baidal, J. A., Celdrán-Bernabeu, M. A., Mazón, J.-N., \& Perles-Ivars, Á. F. (2017). Smart destinations and the evolution of ICTs: a new scenario for destination management? Current Issues in Tourism, In press(October), 1-20. http://doi.org/10.1080/13683500.2017.1388771

Jovicic, D. Z. (2016). Key issues in the conceptualization of tourism destinations. Tourism Geographies, 1-13. http://doi.org/10.1080/14616688.2016.1183144 RESEARCH

Kim, H., Xiang, Z., \& Fesenmaier, D. R. (2015). Use of The Internet for Trip Planning: A Generational Analysis. Journal of Travel \& Tourism Marketing, 32(3), 276-289. http://doi.org/10.1080/10548408.2014.896765

Koo, C., Yoo, K.-H., Lee, J.-N., \& Zanker, M. (2016). Special section on generative smart tourism systems and management: Man-machine interaction. International Journal of Information Management, 36(6), 1301-1305. http://doi.org/10.1016/j.ijinfomgt.2016.05.015 
Kruger, M., \& Saayman, M. (2015). Consumer preferences of Generation Y Evidence from live music tourism event performances in South Africa. Journal of Vacation Marketing, 21(4), $366-382$. http://doi.org/10.1177/1356766715585903

Kuperus, D. (2016). Security and privacy perceptions of millennials vs non-millennials in digital environments. In 7 th IBA Bachelor Thesis Conference (pp. 1-8). Enschede, The Netherlands. Retrieved from http://essay.utwente.nl/70127/1/Kuperus_BA_BMS.pdf

Leask, A., Fyall, A., \& Barron, P. (2013). Generation Y: opportunity or challenge-strategies to engage Generation Y in the UK attractions' sector. Current Issues in Tourism, 16(1), 17-46. http://doi.org/10.1080/13683500.2011.642856

Lee, C. H., \& Cranage, D. A. (2011). Personalisation-privacy paradox: The effects of personalisation and privacy assurance on customer responses to travel Web sites. Tourism Management, 32(5), $987-994$. https://doi.org/10.1016/j.tourman.2010.08.011

Leung, D., Law, R., van Hoof, H., \& Buhalis, D. (2013). Social Media in Tourism and Hospitality: A Literature Review. Journal of Travel \& Tourism Marketing, 30(1-2), 3-22. https://doi.org/10.1080/10548408.2013.750919

Leung, X. Y., Bai, B., \& Stahura, K. A. (2015). The marketing effectiveness of social media in the hotel industry: A comparison of Facebook and Twitter. Journal of Hospitality \& Tourism Research, 39(2), 147-169. https://doi.org/10.1177/1096348012471381

Mannheim, K. (1970). The problem of generations. Psychoanalytic Review, 57(3), 378.

National Statistics Institute. (2016). Resident population. National results. Retrieved from http://www.ine.es/jaxiT3/Datos.htm?t=9663

Neuhofer, B., Buhalis, D., \& Ladkin, A. (2012). Conceptualising technology enhanced destination experiences. Journal of Destination Marketing and Management, 1(1-2), 36-46. http://doi.org/10.1016/j.jdmm.2012.08.001

Neuhofer, B., Buhalis, D., \& Ladkin, A. (2015). Smart technologies for personalized experiences: a case study in the hospitality domain. Electronic Markets, 25, 243-254. http://doi.org/10.1007/s12525-015-0182-1

Nusair, K. K., Parsa, H. G., \& Cobanoglu, C. (2011). Building a model of commitment for Generation Y: An empirical study on e-travel retailers. Tourism Management, 32(4), 833-843. http://doi.org/doi:10.1016/j.tourman.2010.07.008

Pearce, P. L. (2005). Tourist behaviour: Themes and conceptual schemes. Clevedon: Channel View Publications.

Pendergast, D. (2010). Getting to know the Y Generation. In P. Benckendorff, G. Moscardo, \& D. Pendergast (Eds.), Tourism and Generation $Y$ (pp. 1-15). Wallingford: CABI.

SEGITTUR. (2015). Informe destinos turísticos inteligentes: construyendo el futuro. Retrieved from http://www.segittur.es/opencms/export/sites/segitur/.content/galerias/descargas/proyectos/Libro-Blanco-DestinosTursticos-Inteligentes-construyendo-el-futuro.pdf

Solnet, D., \& Hood, A. (2008). Generation Y as hospitality employees: Framing a research agenda. Journal of Hospitality and Tourism Management, 15(1), 59-68. http://doi.org/10.1375/jhtm.15.59

Tabachnik, B. G., \& Fidell, L. S. (2007). Using Multivariate Statistics (5th ed.). Boston: Pearson

Tussyadiah, I. P., \& Fesenmaier, D. R. (2009). Mediating Tourist Experiences. Access to Places via Shared Videos. Annals of Tourism Research, 36(1), 24-40. http://doi.org/10.1016/j.annals.2008.10.001

Venkatesh, V., Morris, M. G., Davis, G. B., \& Davis, F. D. (2003). User acceptance of information technology: Toward a unified view. MIS Quarterly, 27(3), 425-478.

Vukic, M., Kuzmanovic, M., \& Kostic Stankovic, M. (2015). Understanding the Heterogeneity of Generation Y's Preferences for Travelling: a Conjoint Analysis Approach. International Journal of Tourism Research, 17(5), 482491. http://doi.org/10.1002/jtr.2015

Wang, D., Li, X. R., \& Li, Y. (2013). China's "smart tourism destination" initiative: A taste of the service-dominant logic. Journal of Destination Marketing \& Management, 2(2), 59-61. https://doi.org/10.1016/j.jdmm.2013.05.004

Wang, D., Xiang, Z., \& Fesenmaier, D. R. (2014). Adapting to the mobile world: A model of smartphone use. Annals of Tourism Research, 48, 11-26. http://doi.org/10.1016/j.annals.2014.04.008

Wang, D., Xiang, Z., \& Fesenmaier, D. R. (2016). Smartphone Use in Everyday Life and Travel. Journal of Travel Research, 55(1), 52-63. https://doi.org/10.1177/0047287514535847

Wang, X., Li, X. R., Zhen, F., \& Zhang, J. (2016). How smart is your tourist attraction?: Measuring tourist preferences of smart tourism attractions via a FCEM-AHP and IPA approach. Tourism Management, 54, 309-320. http://doi.org/10.1016/j.tourman.2015.12.003

World Bank. (2016). World Development Indicators: Population dynamics. Retrieved from http://wdi.worldbank.org/table/2.1

Xiang, Z., \& Fesenmaier, D. R. (2017). Big Data Analytics, Tourism Design and Smart Tourism. In Z. Xiang \& D. R. Fesenmaier (Eds.), Analytics in Smart Tourism Design (pp. 299-307). Switzerland: Springer.

Xiang, Z., Magnini, V. P., \& Fesenmaier, D. R. (2015). Information technology and consumer behavior in travel and tourism: Insights from travel planning using the internet. Journal of Retailing and Consumer Services, 22, $244-249$. http://doi.org/10.1016/j.jretconser.2014.08.005

Xiang, Z., Tussyadiah, I., \& Buhalis, D. (2015). Smart destinations: Foundations, analytics, and applications. Journal of Destination Marketing \& Management, 4, 143-144. http://doi.org/10.1016/j.jdmm.2015.07.001 